\title{
Staphylococcus aureus Isolated from Ruminants with Mastitis in Northern Greece Dairy Herds: Genetic Relatedness and Phenotypic and Genotypic Characterization
}

\author{
Charalampos Kotzamanidis ${ }^{1, *}\left(\mathbb{D}\right.$, George Vafeas ${ }^{1}\left(\mathbb{D}\right.$, Virginia Giantzi ${ }^{1}$, Sofia Anastasiadou ${ }^{1}$, \\ Stavros Mygdalias ${ }^{1}{ }^{1}$, Andigoni Malousi ${ }^{2}{ }^{\mathbb{D}}$, Ekateriniadou Loukia ${ }^{1}$, Sergelidis Daniel ${ }^{3}$ and Antonios Zdragas ${ }^{1}$ \\ 1 Hellenic Agricultural Organisation-DEMETER, Veterinary Research Institute of Thessaloniki, Campus of \\ Thermi, 57001 Thermi, Greece; vvafeas@vri.gr (G.V.); vgiantzi@vri.gr (V.G.); anastasiadousof@yahoo.gr (S.A.); \\ stavrosmyg@gmail.com (S.M.); ekateriniadou@vri.gr (E.L.); zdragas@vri.gr (A.Z.) \\ 2 Lab of Biological Chemistry, School of Medicine, Aristotle University of Thessaloniki, 54124 Thessaloniki, \\ Greece; andigoni@auth.gr \\ 3 Laboratory of Hygiene of Foods of Animal Origin—Veterinary Public Health, School of Veterinary Medicine, \\ Aristotle University of Thessaloniki, 54124 Thessaloniki, Greece; dsergkel@vet.auth.gr \\ * Correspondence: kotzam@vri.gr
}

check for updates

Citation: Kotzamanidis, C.; Vafeas, G.; Giantzi, V.; Anastasiadou, S.; Mygdalias, S.; Malousi, A.; Loukia, E.; Daniel, S.; Zdragas, A. Staphylococcus aureus Isolated from Ruminants with Mastitis in Northern Greece Dairy Herds: Genetic Relatedness and Phenotypic and Genotypic

Characterization. Toxins 2021, 13, 176. https://doi.org/10.3390/ toxins 13030176

Received: 17 January 2021

Accepted: 22 February 2021

Published: 25 February 2021

Publisher's Note: MDPI stays neutral with regard to jurisdictional claims in published maps and institutional affiliations.

Copyright: (c) 2021 by the authors. Licensee MDPI, Basel, Switzerland. This article is an open access article distributed under the terms and conditions of the Creative Commons Attribution (CC BY) license (https:// creativecommons.org/licenses/by/ $4.0 /)$.

\begin{abstract}
Staphylococcus aureus is the most common mastitis-related pathogen in dairy cattle, goats, and sheep worldwide. However, the population structure and genomic characteristics of mastitisassociated S. aureus in small ruminants are limited. Furthermore, the genotypic and phenotypic characteristics involved in the pathogenicity of $S$. aureus have been thoroughly defined, yet their association with the severity of mastitis is not fully established. Here, we performed genotyping by pulsed-field gel electrophoresis (PFGE) and spa analyses to assess the genetic diversity and relatedness of $162 \mathrm{~S}$. aureus strains recovered from clinical mastitis (CM) and subclinical mastitis (SCM) cases from goats, sheep, and bovines. PFGE analysis revealed 108 distinguishable pulsotypes and 3 main clusters that comprised isolates from the three host species, while according to spa typing, 32 different spa types were identified. Genotypic analysis revealed a spreading of genetically related or indistinguishable S. aureus strains among ovine, caprine, and bovine farms of distant geographical regions. In total, 28 different staphylococcal enterotoxin (SE) gene profiles were observed, revealing a diverse range of SE genes among isolates. By evaluating the antimicrobial resistance, we found low phenotypic antimicrobial resistance among all ruminant isolates. We also performed multiple correspondence analysis, which indicated that the presence of the sec gene, biofilm production, and high autoaggregation ability are associated with CM cases.
\end{abstract}

Keywords: mastitis; Staphylococcus aureus; staphylococcal enterotoxin; ruminants; PFGE; spa typing; antimicrobial resistance; biofilm; autoaggregation

Key Contribution: This study demonstrates that sheep, goats, and bovines are exposed to a broad range of genetically diverse $S$. aureus strains that do not represent host-specific genetic populations and that the outcome of mastitis in ruminants is associated with specific genotypic and phenotypic traits of S. aureus.

\section{Introduction}

Mammary infection of ruminants leading to subclinical and clinical mastitis is associated with severe economic losses due to the reduction in milk yield and milk quality and the cost of treatment [1] and has also an impact on animal welfare [2]. Staphylococcus aureus is the most common mastitis-related pathogen in dairy cattle, goats, and sheep [3,4], with infected animals frequently shedding the bacterium into their milk [5]. In humans, epidemiological studies have identified $S$. aureus as the most common agent involved in food poisoning upon ingestion of foods containing pre-formed staphylococcal enterotoxins 
(SEs) [6]. Furthermore, methicillin-resistant S. aureus (MRSA) constitutes a serious public health concern, and it has been proved that infections in the community and subsequent foodborne outbreaks can also be caused by livestock-associated (LA) MRSA, due to the handling and consumption of contaminated food of animal origin [7].

Intramammary infection in animals is caused by $S$. aureus strains with the capacity to produce a variety of virulence factors such as antigens, toxins, and various resistance proteins [8]. Staphylococcal enterotoxins are considered to play an important role in the development of mastitis, since $S$. aureus isolates from cases of mastitis had a higher prevalence of enterotoxin genes than isolates from milk of cows without mastitis [9], and in addition, SE genes were found to be related with the severity of bovine mastitis [10]. The ability of S. aureus to form biofilm is also considered a crucial virulence trait [11], while the $S$. aureus property of autoaggregation is often associated with pathogenicity [12]

Although the population structure and genomic characteristics of $S$. aureus from bovines have been reported, the number of systematic studies and analogous data for S. aureus isolated from small ruminants, and in particular goats, is very limited [11,13]. Greece is one of the European countries with a large population of small ruminants. Numerous studies have identified that $S$. aureus is one of the most commonly found pathogens in bovine, caprine, and ovine raw milk, while the bacterium has been detected in $40 \%, 31-80 \%$, and $24-63 \%$ of the examined bulk tank milk from Greek dairy bovine, goat, and sheep farms, respectively [14-16].

Previous studies have shown that $S$. aureus from goats and sheep are closely related and distinct to bovine ones and that there is a different clonal composition between small ruminants and cows. In these studies, different genotyping methods, including spa sequence typing, ribosomal spacer PCR (RS-PCR) virulence gene profiling, and multilocus sequence typing (MLST) $[13,17,18]$, have been used for the characterization of $S$. aureus strains, enabling to evaluate their genetic relatedness. In contrast, other studies based on pulsed-field gel electrophoresis (PFGE) analysis have shown that closely related mastitisassociated genotypes of $S$. aureus are capable of colonizing and infecting different host species such as sheep, goats, and bovines [19-21]. The discriminatory power of PFGE is considered relatively higher compared to other typing methods such as MLST and spa typing [22]. However, a general lack of information exists regarding large-scale studies based on PFGE for the genotyping and the subsequent investigation of S. aureus population structure in small ruminants.

Since there is little information about and contradictory results on the genomic population structure of mastitis-associated S. aureus recovered from sheep, goats, and bovines, the ecology and transmission of this bacterium in the farm environment remains unclear and studies on the characterization of clinical mastitis (CM) as well as subclinical mastitis (SCM)-associated isolates from small ruminants are needed. In previous works we investigated the prevalence of $S$. aureus and MRSA in cattle, sheep, and goat farms as well as in dairy industries in Greece, and we also accessed their genetic diversity [16,23]. In this study, to obtain more insights into the transmission routes and infection sources of this important pathogen in the farm environment, we presented molecular typing analyses, antimicrobial susceptibility testing, and cell surface traits to characterize and compare bovine, ovine, and caprine S. aureus isolates from CM and SCM cases. The objectives of the present study were (i) to describe by PFGE and spa-typing analysis the genetic diversity of S. aureus isolated from cases of ovine, caprine, and bovine mastitis in order to evaluate the population structure and genetic relatedness of $S$. aureus recovered from different ruminant species and (ii) to investigate whether specific genomic and phenotypic characteristics of the pathogen are associated with CM or SCM in ruminants.

\section{Results}

\subsection{Distribution of Virulence and Resistance Genes}

All the 162 ruminant isolates tested positive for coa and the species-specific nuc genes, confirming the phenotypic identification of the selected S. aureus isolates. However, none of 
the isolates tested positive for the presence of either of the methicillin resistance genes, mecA or mecC. Concerning S. aureus toxins, one or more of the 10 types were detected in $109(67.3 \%, 109 / 162)$ of the analyzed S. aureus isolates (Table 1$)$.

Table 1. Detection of toxin genes in Staphylococcus aureus strains isolated from cases of ovine, caprine, and bovine mastitis.

\begin{tabular}{|c|c|c|c|c|c|c|}
\hline & \multicolumn{6}{|c|}{ No. of Isolates (\%) } \\
\hline & \multicolumn{2}{|c|}{ Ovine $(n=97)$} & \multicolumn{2}{|c|}{ Caprine $(n=29)$} & \multirow{2}{*}{$\begin{array}{c}\text { Bovine }(\mathrm{n}=36) \\
\text { Clinical }\end{array}$} & \multirow{2}{*}{ Total $(\mathrm{n}=162)$} \\
\hline & Clinical $(n=34)$ & Subclinical $(n=63)$ & Clinical $(n=4)$ & Subclinical $(n=25)$ & & \\
\hline \multicolumn{7}{|l|}{ Toxin genes } \\
\hline sea & $0(0)$ & $9(14.3)$ & $0(0)$ & $1(4.0)$ & $0(0)$ & $10(6.2)$ \\
\hline$s e b$ & $5(14.7)$ & $19(30.2)$ & $1(25.0)$ & $7(28.0)$ & $12(33.3)$ & 44 (27.1) \\
\hline $\mathrm{sec}$ & $11(32.3)$ & $18(28.5)$ & $0(0)$ & $8(32.0)$ & $16(44.4)$ & $53(32.7)$ \\
\hline sed & $0(0)$ & $4(6.3)$ & $0(0)$ & $8(0)$ & $1(2.8)$ & $7(4.3)$ \\
\hline see & $0(0)$ & $0(0)$ & $0(0)$ & $0(0)$ & $0(0)$ & $0(0)$ \\
\hline seh & $0(0)$ & $3(4.8)$ & $0(0)$ & $0(0)$ & $0(0)$ & $3(1.9)$ \\
\hline seg & $1(2.9)$ & $3(4.8)$ & $0(0)$ & $2(8.0)$ & $0(0)$ & $6(3.7)$ \\
\hline sei & $4(11.8)$ & $18(28.5)$ & $0(0)$ & $7(28.0)$ & $0(0)$ & $29(17.9)$ \\
\hline sej & $1(2.9)$ & $8(12.7)$ & $1(25.0)$ & $3(12.0)$ & $8(22.2)$ & $21(13.0)$ \\
\hline pol & $0(0)$ & $0(0)$ & $0(0)$ & $0(0)$ & $0(0)$ & $0(0)$ \\
\hline tsst & $1(2.9)$ & $0(0)$ & $0(0)$ & $0(0)$ & $1(2.8)$ & $2(1.2)$ \\
\hline \multicolumn{7}{|l|}{$\begin{array}{l}\text { Toxin gene } \\
\text { patterns }\end{array}$} \\
\hline sea & $0(0)$ & $2(3.2)$ & $0(0)$ & $0(0)$ & $0(0)$ & $2(1.2)$ \\
\hline$s e b$ & $2(5.9)$ & $5(7.9)$ & $1(25.0)$ & $1(4.0)$ & $2(5.5)$ & $11(6.7)$ \\
\hline $\mathrm{sec}$ & $11(32.3)$ & $10(15.9)$ & $0(0)$ & $0(0)$ & $10(27.8)$ & $34(21.0)$ \\
\hline sed & $0(0)$ & $1(1.6)$ & $0(0)$ & $0(0)$ & $0(0)$ & $1(0.6)$ \\
\hline seh & $0(0)$ & $1(1.6)$ & $0(0)$ & $0(0)$ & $0(0)$ & $1(0.6)$ \\
\hline sei & $0(0)$ & $6(9.5)$ & $0(0)$ & $0(0)$ & $0(0)$ & $6(3.7)$ \\
\hline sej & $0(0)$ & $0(0)$ & $1(25.0)$ & $1(4.0)$ & $5(13.9)$ & $7(4.3)$ \\
\hline tsst & $1(2.9)$ & $0(0)$ & $0(0)$ & $0(0)$ & $0(0)$ & $1(0.6)$ \\
\hline sea, seb & $0(0)$ & $1(1.6)$ & $0(0)$ & $0(0)$ & $0(0)$ & $1(0.6)$ \\
\hline sea, sei & $0(0)$ & $0(0)$ & $0(0)$ & $1(4.0)$ & $0(0)$ & $1(0.6)$ \\
\hline sea, sej & $0(0)$ & $1(1.6)$ & $0(0)$ & $0(0)$ & $0(0)$ & $1(0.6)$ \\
\hline seb, sec & $0(0)$ & $2(3.2)$ & $0(0)$ & $1(4.0)$ & $6(16.7)$ & $9(5.6)$ \\
\hline seb, sei & $2(5.9)$ & $4(6.3)$ & $0(0)$ & $2(8.0)$ & $0(0)$ & $8(4.9)$ \\
\hline seb, sej & $0(0)$ & $0(0)$ & $0(0)$ & $0(0)$ & $3(8.3)$ & $3(1.9)$ \\
\hline sec, sei & $0(0)$ & $0(0)$ & $0(0)$ & $1(4.0)$ & $0(0)$ & $1(0.6)$ \\
\hline sec, sej & $0(0)$ & $0(0)$ & $0(0)$ & $1(4.0)$ & $0(0)$ & $1(0.6)$ \\
\hline sed, seg & $0(0)$ & $0(0)$ & $0(0)$ & $1(4.0)$ & $0(0)$ & $1(0.6)$ \\
\hline sei, sej & $2(5.9)$ & $3(4.8)$ & $0(0)$ & $0(0)$ & $0(0)$ & $4(2.5)$ \\
\hline sea, sec, seh & $0(0)$ & $2(3.2)$ & $0(0)$ & $0(0)$ & $0(0)$ & $2(1.2)$ \\
\hline sea, sei, sej & $0(0)$ & $0(0)$ & $0(0)$ & $0(0)$ & $1(2.8)$ & $1(0.6)$ \\
\hline seb, sec, sei & $0(0)$ & $1(1.6)$ & $0(0)$ & $2(8.0)$ & $0(0)$ & $3(1.9)$ \\
\hline seb, sed, seg & $0(0)$ & $2(3.2)$ & $0(0)$ & $1(4.0)$ & $0(0)$ & $3(1.9)$ \\
\hline seb, sed, tsst & $0(0)$ & $0(0)$ & $0(0)$ & $0(0)$ & $1(2.8)$ & $1(0.6)$ \\
\hline seb, seg, sei & $1(2.9)$ & $0(0)$ & $0(0)$ & $0(0)$ & $0(0)$ & $1(0.6)$ \\
\hline sed, seg, sej & $0(0)$ & $1(1.6)$ & $0(0)$ & $0(0)$ & $0(0)$ & $1(0.6)$ \\
\hline sea, seb, sec, sei & $0(0)$ & $1(1.6)$ & $0(0)$ & $0(0)$ & $0(0)$ & $1(0.6)$ \\
\hline sea, seb, sei, sej & $0(0)$ & $1(1.6)$ & $0(0)$ & $0(0)$ & $0(0)$ & $1(0.6)$ \\
\hline seb, sec, sei, sej & $0(0)$ & $2(3.2)$ & $0(0)$ & $0(0)$ & $0(0)$ & $2(1.2)$ \\
\hline
\end{tabular}

The sec $(32.7 \%, 53 / 162)$, seb $(27.1 \%, 44 / 162)$, sei $(17.9 \%, 29 / 162)$, and $\operatorname{sej}(13.0 \%, 21 / 162)$ genes were the most common genes detected among all the isolates, followed by sea $(6.2 \%$, $10 / 162)$, sed $(4.3 \%, 7 / 162)$, seg $(3.7 \%, 6 / 162)$, and seh $(1.9 \%, 3 / 162)$, while none of the isolates carried the see gene. The tsst gene was only identified in two S. aureus isolates $(1.2 \%, 2 / 162)$, one ovine and one bovine, while none of the isolates tested positive for the $l u k F-P V$ gene encoding the Panton-Valentine leukocidin (PVL) toxin. One or more enterotoxin genes were detected simultaneously in 38.9\% (63/162) of all 162 isolates, and in total, 28 different virulence gene profiles were observed. Among them, the most frequent toxin-gene combinations were seb, sec (9 isolates) and seb, sei (8 isolates). The largest diversity, 15 toxin gene profiles, was found among ovine S. aureus, followed by caprine and bovine isolates, with 12 and 7 profiles, respectively. 


\subsection{PFGE Genotyping}

All the 162 S. aureus isolates were typeable by PFGE following digestion by restriction enzyme smaI, revealing 108 distinguishable pulsotypes (59 among 97 ovine isolates, 25 among 29 caprine isolates, 24 among 36 bovine isolates) (Figure 1 and Figure S1).

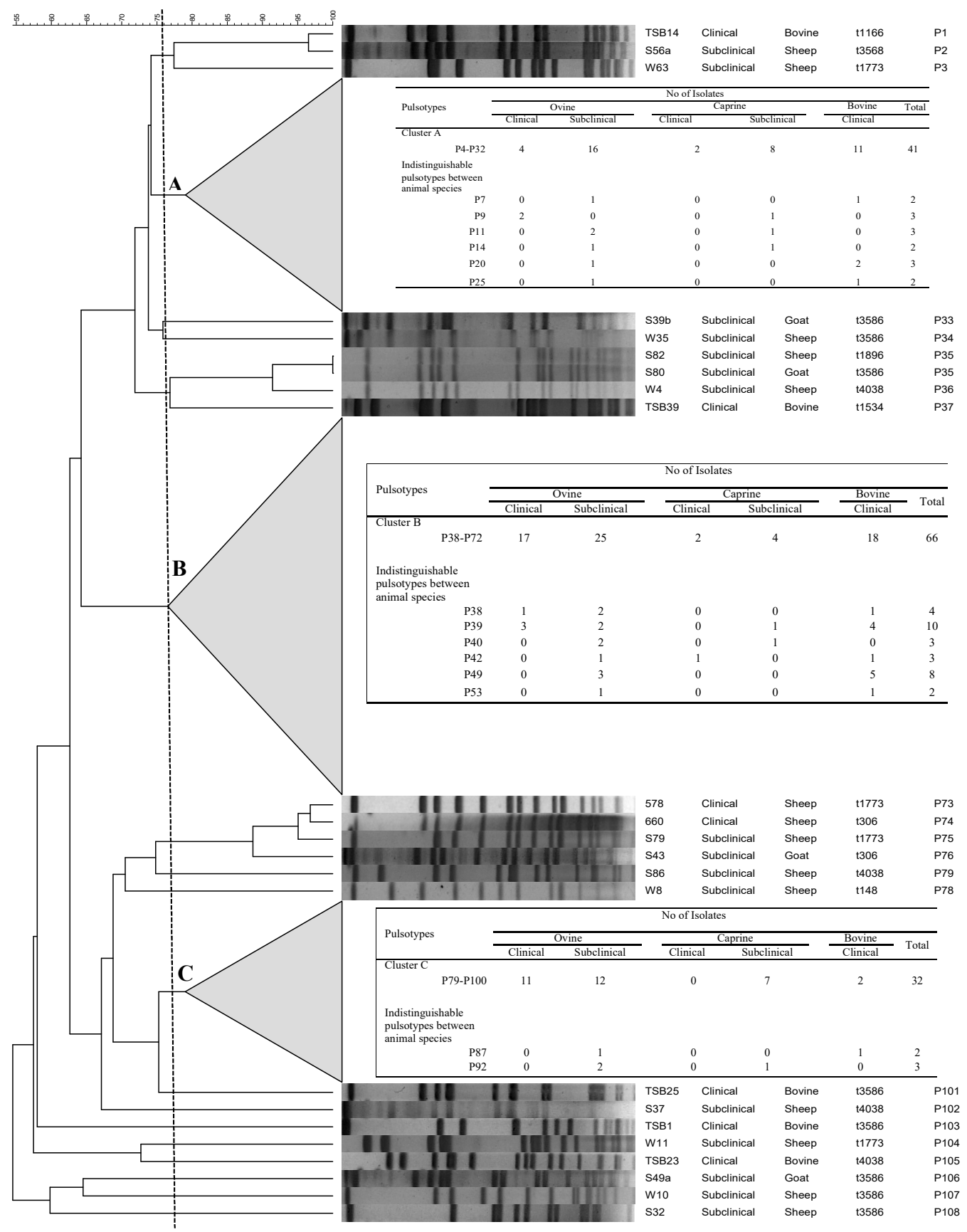

Figure 1. Dendrogram of smaI pulsed-field gel electrophoresis (PFGE) macrorestriction patterns of S. aureus isolated from cases of ovine, caprine, and bovine mastitis. The dendrogram is based on analysis by the unweighted pair group with the arithmetic averages clustering method. Clusters $\mathrm{A}$, $\mathrm{B}$, and $\mathrm{C}$ were defined at a similarity level of $75 \%$.

The Simpson index of discrimination was 0.990 . At a similarity level of $75 \%$ or above, the majority of S. aureus isolates $(83.3 \%, 135 / 162)$ were assigned into three clusters (A, B, and $\mathrm{C}$ ), which shows complete host diversity, indicating the absence of association with host species for these clusters. In more detail, cluster A consisted of ovine (20), caprine (10), 
and bovine (11) isolates obtained from $\mathrm{CM}$ or SCM cases of the three host species. Looking at B, 39 ovine, 6 caprine, and 18 bovine clinical- or subclinical-mastitis-associated isolates belonged to this cluster. Finally, cluster $\mathrm{C}$ almost consisted of ovine and caprine isolates, containing 23 ovine, 7 caprine, and 2 bovine isolates from both CM and SCM cases.

Interestingly, indistinguishable pulsotypes shared by ovine, caprine, and bovine isolates were identified: pulsotypes P7, P20, P25, P38, P42, P49, P53, and P87 were shared by ovine and bovine isolates; pulsotypes P9, P11, P14, P35, P40, and P92 were shared by ovine and caprine isolates; while P39 and P42 were common to all ruminant species. Furthermore, looking at indistinguishable pulsotypes, we could identify common pulsotypes among isolates obtained from CM and SCM cases (P7, P9, P20, P25, P38, P39, P42, P49, P53, P87).

\subsection{Identification and Distribution of spa Types}

To access the clonal profile and diversity of the S. aureus population, spa typing and PFGE were performed. According to spa typing, 32 different spa types were identified and the majority of them $(17 / 32)$ were represented from single isolates, revealing the high diversity of the S. aureus population (Table 2). Among ovine isolates, a diverse range of spa types was detected (27 spa types), while the caprine- and bovine-associated isolates belonged to 10 and 12 different spa types, respectively. The most prevalent spa types were $\mathrm{t} 3586(\mathrm{n}=48 ; 30.0 \%), \mathrm{t} 4038(\mathrm{n}=28 ; 17.3 \%)$, and $\mathrm{t} 1773(\mathrm{n}=13 ; 8.0 \%)$, each of them consisting of isolates from all host species, comprising the majority (53 ovine, 15 caprine, 21 bovine; $55.0 \%$ ) of all isolates. Two minimum spanning trees based on spa-typing results of the S. aureus population, depending on the host animal (Figure 2a) and the severity of mastitis (Figure $2 b$ ), were constructed. These graphs showed the spa type frequencies and the genetic distance between them. The graph in Figure 2a illustrates a marked diversity among ovine, caprine, and bovine isolates, while Figure $2 \mathrm{~b}$ shows that specific spa types are exclusively associated with $\mathrm{CM}(\mathrm{t} 1166, \mathrm{t} 2678, \mathrm{t} 5728$, and $\mathrm{t} 524)$ or SCM (t548) in different animal species.

Table 2. Distribution of spa types in S. aureus isolates by host animal and severity of mastitis.

\begin{tabular}{|c|c|c|c|c|c|c|}
\hline \multirow{3}{*}{ spa Type } & \multicolumn{6}{|c|}{ No. of Isolates (\%) } \\
\hline & \multicolumn{2}{|c|}{ Ovine $(n=97)$} & \multicolumn{2}{|c|}{ Caprine $(n=29)$} & \multirow{2}{*}{$\begin{array}{c}\text { Bovine }(\mathrm{n}=36) \\
\text { Clinical }\end{array}$} & \multirow{2}{*}{ Total $(n=162)$} \\
\hline & Clinical $(\mathrm{n}=34)$ & Subclinical $(n=63)$ & Clinical $(n=4)$ & Subclinical $(n=25)$ & & \\
\hline t012 & $1(2.9)$ & $0(0)$ & $0(0)$ & $0(0)$ & $0(0)$ & $1(0.6)$ \\
\hline $\mathrm{t} 031$ & $1(2.9)$ & $0(0)$ & $0(0)$ & $0(0)$ & $0(0)$ & $1(0.6)$ \\
\hline t085 & $0(0)$ & $1(1.6)$ & $0(0)$ & $0(0)$ & $0(0)$ & $1(0.6)$ \\
\hline $\mathrm{t} 116$ & $0(0)$ & 1 (1.6) & $0(0)$ & $0(0)$ & $0(0)$ & $1(0.6)$ \\
\hline t1166 & $1(2.9)$ & $0(0)$ & $0(0)$ & $0(0)$ & $1(2.8)$ & $2(1.2)$ \\
\hline t12028 & $0(0)$ & $0(0)$ & $0(0)$ & $0(0)$ & $1(2.8)$ & $1(0.6)$ \\
\hline t148 & $0(0)$ & $1(1.6)$ & $0(0)$ & $0(0)$ & $0(0)$ & $1(0.6)$ \\
\hline t14993 & $0(0)$ & 1 (1.6) & $0(0)$ & $0(0)$ & $0(0)$ & $1(0.6)$ \\
\hline t1532 & $0(0)$ & $0(0)$ & $0(0)$ & $0(0)$ & $1(2.8)$ & $1(0.6)$ \\
\hline $\mathrm{t} 1534$ & $0(0)$ & $1(1.6)$ & $0(0)$ & $1(4.0)$ & $1(2.8)$ & $3(1.8)$ \\
\hline t1773 & $7(20.6)$ & $4(6.3)$ & $1(25.0)$ & $0(0)$ & $1(2.8)$ & $13(8.0)$ \\
\hline t1896 & $0(0)$ & $2(3.2)$ & $0(0)$ & $0(0)$ & $1(2.8)$ & $3(1.8)$ \\
\hline t2516 & $0(0)$ & $0(0)$ & $0(0)$ & $0(0)$ & $1(2.8)$ & $1(0.6)$ \\
\hline $\mathrm{t} 267$ & $0(0)$ & 1 (1.6) & $0(0)$ & $0(0)$ & $0(0)$ & $1(0.6)$ \\
\hline t2678 & $4(11.8)$ & $0(0)$ & $0(0)$ & $0(0)$ & $4(11.1)$ & $8(4.9)$ \\
\hline $\mathrm{t} 306$ & $1(2.9)$ & $2(3.2)$ & $0(0)$ & $2(8.0)$ & $0(0)$ & $5(3.1)$ \\
\hline t3568 & $1(2.9)$ & $6(9.5)$ & $0(0)$ & $1(4.0)$ & $0(0)$ & 8 (4.9) \\
\hline t3586 & $8(23.5)$ & $18(28.6)$ & $0(0)$ & $8(32.0)$ & $14(38.9)$ & $48(30.0)$ \\
\hline t359 & $1(2.9)$ & $0(0)$ & $0(0)$ & $0(0)$ & $0(0)$ & $1(0.6)$ \\
\hline t3739 & $1(2.9)$ & $0(0)$ & $0(0)$ & $0(0)$ & $0(0)$ & $1(0.6)$ \\
\hline $\mathrm{t} 4038$ & $2(5.9)$ & $14(22.2)$ & $1(25.0)$ & $5(20.0)$ & $6(16.7)$ & $28(17.3)$ \\
\hline $\mathrm{t} 524$ & $3(8.8)$ & $0(0)$ & $1(25.0)$ & $0(0)$ & $0(0)$ & $4(2.5)$ \\
\hline t5428 & $1(2.9)$ & $0(0)$ & $0(0)$ & $0(0)$ & $0(0)$ & $1(0.6)$ \\
\hline $\mathrm{t} 548$ & $0(0)$ & $2(3.2)$ & $0(0)$ & $1(4.0)$ & $0(0)$ & $3(1.8)$ \\
\hline $\mathrm{t} 5728$ & $1(2.9)$ & $0(0)$ & $0(0)$ & $0(0)$ & $1(2.8)$ & $2(1.2)$ \\
\hline t6058 & $0(0)$ & $0(0)$ & $0(0)$ & $0(0)$ & $1(2.8)$ & $1(0.6)$ \\
\hline t693 & $0(0)$ & $1(1.6)$ & $0(0)$ & $0(0)$ & $0(0)$ & $1(0.6)$ \\
\hline t7008 & $1(2.9)$ & 1 (1.6) & $0(0)$ & $0(0)$ & $0(0)$ & $2(1.2)$ \\
\hline t701 & $0(0)$ & $2(3.2)$ & $0(0)$ & $0(0)$ & $0(0)$ & $2(1.2)$ \\
\hline t7946 & $0(0)$ & $0(0)$ & $0(0)$ & $1(4.0)$ & $0(0)$ & $1(0.6)$ \\
\hline t7947 & $0(0)$ & $3(4.8)$ & $1(25.0)$ & $0(0)$ & $0(0)$ & $4(2.5)$ \\
\hline t891 & $0(0)$ & 1 (1.6) & $0(0)$ & $0(0)$ & $0(0)$ & $1(0.6)$ \\
\hline NT & $0(0)$ & 1 (1.6) & $0(0)$ & $6(24.0)$ & $3(8.3)$ & $10(6.2)$ \\
\hline
\end{tabular}




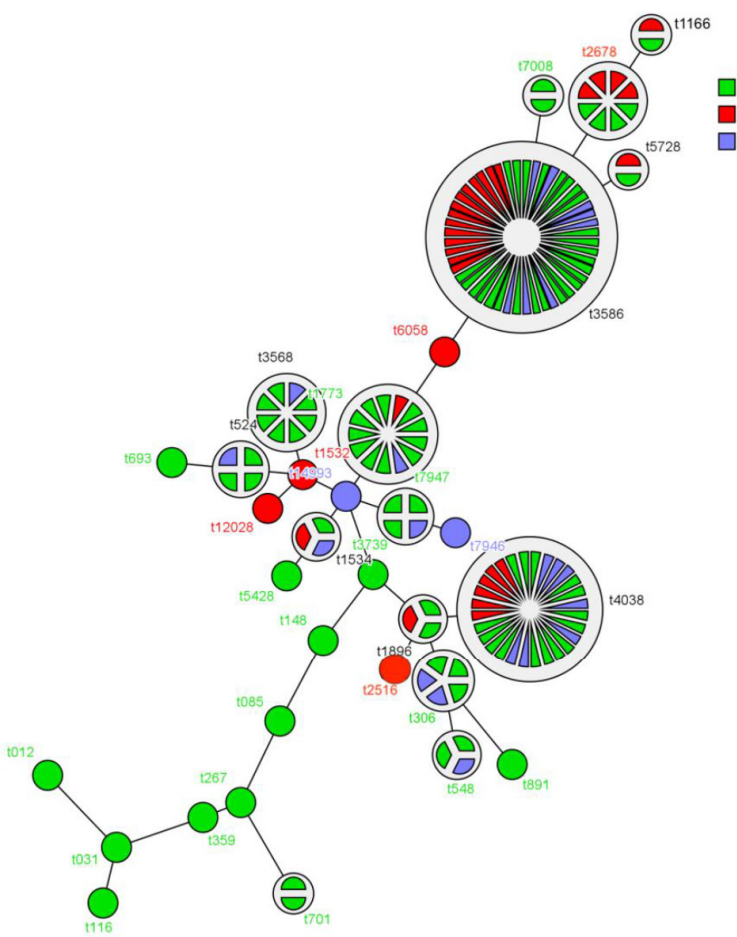

(a)

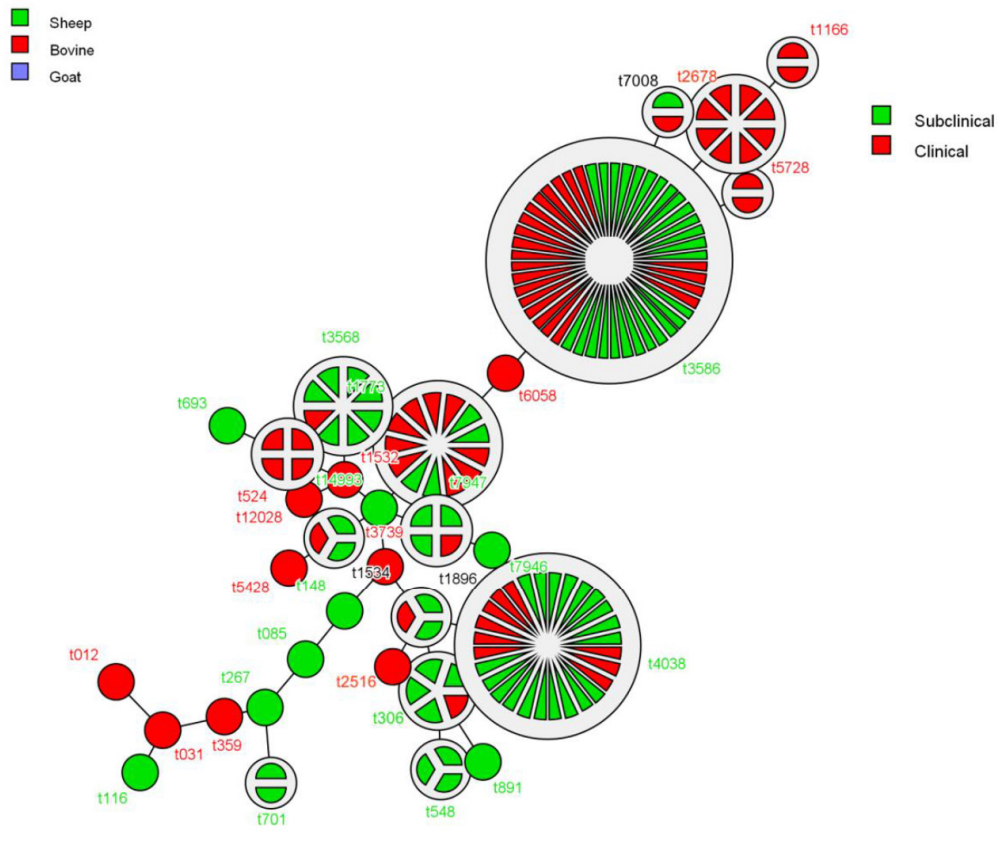

(b)

Figure 2. Minimum spanning trees based on spa-typing results of ovine, caprine, and bovine S. aureus mastitis isolates, depending on the host animal (a) and the severity of mastitis (b). Each spa type is depicted by a single node. The size of the node is proportional to the number of isolates within the spa type, while colored sections represent the host species of the isolates or the severity of mastitis. The distance between the nodes represents the genetic divergence.

\subsection{Phenotypic Antimicrobial Resistance}

According to antimicrobial susceptibility testing, resistance of $S$. aureus isolates to 4 of the 20 antimicrobial agents tested was observed (Table 3). Among all isolates, 43.2\% (70/162) were found to be resistant to at least one antimicrobial agent, with the highest resistance frequency being observed to penicillin $(16.7 \%, 27 / 162)$ and tetracycline $(14.2 \%$, $23 / 162)$, followed by streptomycin $(10.5 \%, 17 / 162)$ and erythromycin $(1.9 \%, 3 / 162)$. In addition, $S$. aureus isolates from bovines exhibited the highest resistance frequency to penicillin $(25.0 \%, 9 / 36)$ and tetracycline $(25.0 \%, 9 / 36)$ compared with sheep and goat isolates. Regarding multiresistance, $8.6 \%(14 / 162)$ of the isolates were resistant to more than one antibiotic. Overall, seven antimicrobial resistance profiles (ARPs) were defined, while two isolates $(1.2 \%)$ were characterized as multidrug resistant (MDR), exhibiting resistance to three different classes of antimicrobials.

\subsection{Biofilm Formation and Cell Surface Traits}

The biofilm formation assay differentiated $S$. aureus isolates into strong, moderate, and weak (Table 3 and Figure S2). The majority $(60.4 \%, 98 / 162)$ of isolates were characterized as strong biofilm producers, followed by isolates with moderate $(34 \%, 55 / 162)$ and weak $(5.6 \%, 9 / 162)$ biofilm formation capacity. With respect to autoaggregation, the majority $(61.7 \%, 100 / 162)$ of the $S$. aureus isolates belonged to the group with low ability. Biofilm formation strength (chi-square $=11.603 ; p=0.003$; significant association at $p<0.01$ ) and autoaggregation ability (chi-square $=59.043 ; p<0.0001$; significant association at $p<0.01$ ) were significantly associated with the severity of mastitis, while all isolates exhibited low cell surface hydrophobicity. 
Table 3. Phenotypic characteristics of S. aureus isolated from cases of ovine, caprine, and bovine mastitis.

\begin{tabular}{|c|c|c|c|c|c|c|}
\hline \multirow{3}{*}{ Phenotype } & \multicolumn{6}{|c|}{ No. of Isolates (\%) } \\
\hline & \multicolumn{2}{|c|}{ Ovine $(n=97)$} & \multicolumn{2}{|c|}{ Caprine $(n=29)$} & \multirow{2}{*}{$\begin{array}{c}\text { Bovine }(\mathrm{n}=\mathbf{3 6}) \\
\text { Clinical }\end{array}$} & \multirow{2}{*}{ Total $(n=162)$} \\
\hline & Clinical $(n=34)$ & Subclinical $(n=63)$ & Clinical $(n=4)$ & Subclinical $(n=25)$ & & \\
\hline \multicolumn{7}{|c|}{ Antimicrobial } \\
\hline \multicolumn{7}{|c|}{ resistance } \\
\hline Penicillin $(\mathrm{P})$ & $10(29.4)$ & $6(9.6)$ & $1(25.0)$ & $1(4.0)$ & $9(25.0)$ & $27(16.7)$ \\
\hline $\begin{array}{l}\text { Erythromycin } \\
\text { (E) }\end{array}$ & $1(2.9)$ & $1(1.6)$ & $0(0)$ & $0(0)$ & $1(2.8)$ & $3(1.9)$ \\
\hline $\begin{array}{l}\text { Tetracycline } \\
\text { (TET) }\end{array}$ & $11(32.4)$ & $2(3.2)$ & $1(25.0)$ & $0(0)$ & $9(25.0)$ & $23(14.2)$ \\
\hline $\begin{array}{l}\text { Streptomycin } \\
\text { (S) }\end{array}$ & $2(5.9)$ & $10(15.9)$ & $0(0)$ & $3(12.0)$ & $2(5.6)$ & 17 (10.5) \\
\hline \multicolumn{7}{|c|}{ Antimicrobial resistance } \\
\hline \multicolumn{7}{|c|}{ patterns } \\
\hline $\mathrm{P}$ & $2(5.9)$ & $4(6.3)$ & $1(25.0)$ & $1(4.0)$ & $5(13.9)$ & $13(8.0)$ \\
\hline E & $1(2.9)$ & $1(1.6)$ & $0(0)$ & $0(0)$ & $1(2.8)$ & $3(4.8)$ \\
\hline TET & $5(14.7)$ & $0(0)$ & $1(25.0)$ & $0(0)$ & $5(13.9)$ & $11(6.8)$ \\
\hline $\mathrm{S}$ & $0(0)$ & $8(12.7)$ & $0(0)$ & $3(12.0)$ & $2(5.6)$ & $13(8.0)$ \\
\hline P-S & $2(5.9)$ & $0(0)$ & $0(0)$ & $0(0)$ & $0(0)$ & $2(1.2)$ \\
\hline P-TET & $6(17.6)$ & $0(0)$ & $0(0)$ & $0(0)$ & 4 (11.1) & $10(6.2)$ \\
\hline P-TET-S & $0(0)$ & $2(3.2)$ & $0(0)$ & $0(0)$ & $0(0)$ & $2(1.2)$ \\
\hline \multicolumn{7}{|c|}{ Biofilm production } \\
\hline \multicolumn{7}{|c|}{ ability } \\
\hline No biofilm & $0(0)$ & $0(0)$ & $0(0)$ & $0(0)$ & $0(0)$ & $0(0)$ \\
\hline Weak & $0(0)$ & $6(9.5)$ & 0 & $3(12.0)$ & 0 & $9(5.6)$ \\
\hline Moderate & $14(41.2)$ & $25(39.7)$ & $2(50.0)$ & $9(36.0)$ & $5(13.9)$ & $55(34.0)$ \\
\hline Strong & $20(58.8)$ & $32(50.8)$ & $2(50.0)$ & $13(52.0)$ & $31(86.1)$ & $98(60.4)$ \\
\hline \multicolumn{7}{|c|}{ Hydrophobicity } \\
\hline Low & $34(100)$ & $63(1000$ & $4(100)$ & $25(100)$ & $36(100)$ & $162(100)$ \\
\hline Medium & $0(0)$ & $0(0)$ & $0(0)$ & $0(0)$ & $0(0)$ & $0(0)$ \\
\hline High & $0(0)$ & $0(0)$ & $0(0)$ & $0(0)$ & $0(0)$ & $0(0)$ \\
\hline \multicolumn{7}{|c|}{ Autoaggregation } \\
\hline \multicolumn{7}{|c|}{ ability } \\
\hline Low & $13(38.2)$ & 55 (87.3) & $0(0)$ & $23(92.0)$ & $9(25.0)$ & $100(61.7)$ \\
\hline High & $21(61.8)$ & $8(12.7)$ & $4(100)$ & $2(8.0)$ & $27(75.0)$ & $62(38.3)$ \\
\hline
\end{tabular}

\subsection{Associations between SE Genes, Genotypic Traits, and Mastitis}

The first two factorial axes produced by multiple correspondence analysis (MCA) were used to compose the factorial plane $1 \times 2$. These two axes represent $32.3 \%$ and $22.55 \%$, respectively, of the total inertia, explaining together $54.85 \%$ of the total variability (Figure 3). It can be observed that the second factorial axis mainly differentiates clinical from subclinical isolates. Correspondence analysis investigating the interaction between biofilm formation, autoaggregation ability, virulence genes, and the severity of mastitis showed that the presence of the sec gene as well as the strong-biofilm-producing and high-autoaggregating S. aureus was associated with CM. On the other hand, moderatebiofilm-forming and low-autoaggregating S. aureus isolates were related to SCM, while the sed and seg genes were not associated with either CM or SCM. 


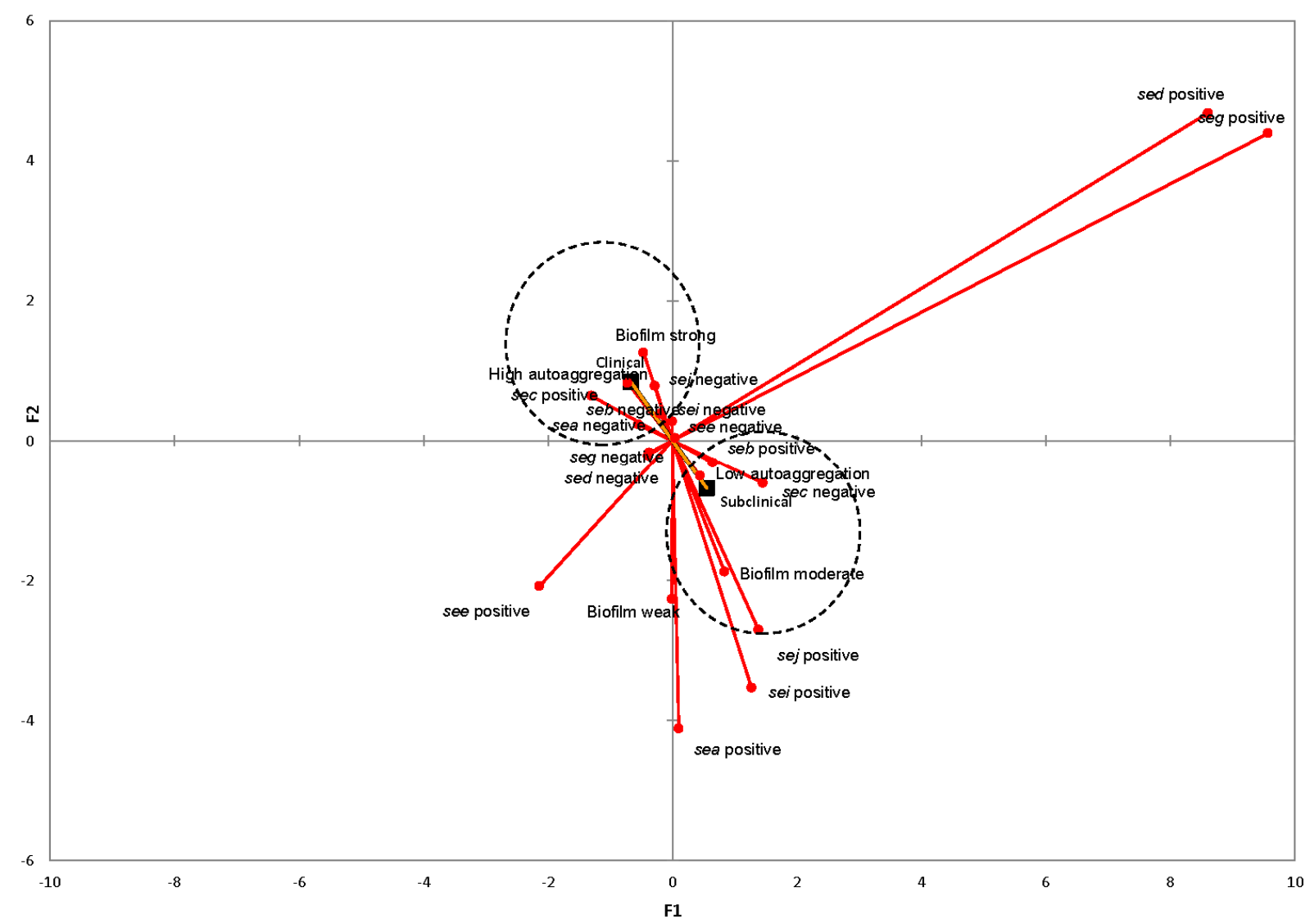

Figure 3. Multiple correspondence analysis (MCA) for the correlation between biofilm formation strength, autoaggregation ability, the presence of virulence genes, and the severity of mastitis of $S$. aureus isolated from cases of ovine, caprine, and bovine clinical and subclinical mastitis. The first two factorial axes display $32.3 \%$ and $22.55 \%$ of the total variability, respectively. Vectors with blocks $(\boldsymbol{\square})$ represent clinical and subclinical mastitis cases.

The results were further tested with a series of chi-square independence tests, which confirmed that the enterotoxin genes (chi-square $=26.753 ; p=0.0001$; significant association at $p<0.01$ ) were significantly associated with the severity of mastitis.

\section{Discussion}

Considering that $S$. aureus is the major cause of mastitis, one of the costliest dairy farm diseases worldwide, and that little information is available regarding the molecular epidemiology of this pathogen in small ruminants, the main objective of this study was to elucidate the population structure and genetic relatedness of S. aureus recovered from sheep, goats, and bovines. To this end, we performed genotyping based on PFGE analysis. In consistence with previous studies, genetic characterization of the isolates by PFGE revealed that ruminants are exposed to a broad range of genetically diverse strains in the farm environment. Genomic variability among the $162 \mathrm{~S}$. aureus isolates was demonstrated by the large number (108) of distinct PFGE patterns, as well as the high value of Simpson's index of diversity $(\mathrm{D}=0.990)$.

The majority of the ovine, caprine, and bovine isolates $(83.3 \%, 135 / 162)$ were grouped together into three main clusters (A, B, and C). Interestingly, all host species in clusters $A$ and $B$ were present in significant proportion, showing host diversity and the absence of association with host species for these clusters. On the other hand, the fact that cluster $C$ comprised almost exclusively ovine and caprine isolates indicates that $S$. aureus from small ruminants may show a closer genetic relationship and also may form a population distinct from the bovine isolates. The main clusters that have been revealed can support the hypothesis that during a period time of five years, in the region of northern Greece, 
three main clones defined by PFGE analysis were shared by ovine, caprine, and bovine mastitis-associated $S$. aureus and started to spread among farms of distant geographical regions. This finding is in agreement, in part, with a previous study that revealed in Greece the existence of similar clones of $S$. aureus isolated from SCM cases of dairy goats among distantly located herds [11]. Studying the genetic relationships between isolates is important for understanding the transmission and spread of a pathogen. However, genetic information obtained is influenced by the choice of method, different sample sizes, type of farming systems, and geographical conditions [18]. In this aspect, previous studies based on MLST, RS-PCR, and spa typing $[13,17,18]$ have demonstrated the genetic diversity of $S$. aureus from ruminants as well as the fact that ovine and caprine isolates are similar and distinct from cattle isolates. Our work, based on PFGE analysis, clearly demonstrates not only the genetic diversity of the $S$. aureus population but the existence of PFGE clones that comprised isolates with considerable genetic similarity from all host species, indicating that $S$. aureus isolates from sheep, goats, and bovines do not represent separate genetic populations. These findings are in line with previous studies that were also based on PFGE $[20,24,25]$. Thus, taking into consideration its high discriminatory power, we conclude that the PFGE method is capable of revealing the population structure of mastitis-associated $S$. aureus recovered from different ruminant species in a specific geographical region. Furthermore, a key finding of the current study was the detection of indistinguishable $S$. aureus pulsotypes from ovine, caprine, and bovine hosts, indicating the existence of specific pathogen strains with the capacity to cause disease in different host species. In addition, the existence of these indistinguishable $S$. aureus isolates is suggestive of bacterial transmission between different animal species/herds.

To better elucidate the population structure of mastitis-associated $S$. aureus from ruminants, we performed spa typing, which also revealed a remarkable genetic diversity among isolates. We found three spa types ( $\mathrm{t} 3586, \mathrm{t} 4038$, and $\mathrm{t} 1773$ ) that contain isolates from all host species, comprising the majority of all isolates. We also found specific spa types that are exclusively associated with CM (t1166, t2678, t5728, and t524) or SCM (t548) in different animal species. In agreement with PFGE, the above findings also support the idea that $S$. aureus isolates from sheep, goats, and bovines do not represent separate genetic populations. Regarding the most prevalent spa types in our study, t1773 was also reported by Merz [17] and Romano [13] as the most prevalent spa type in caprine isolates in Switzerland and northern Italy, respectively, while $\mathrm{t} 3586$ and $\mathrm{t} 4038$ types were identified among MRSA isolates in Greece, from sheep and goats, respectively $[15,16]$.

Overall, our findings support the hypothesis that $S$. aureus from ruminants is a clonal microorganism that spreads among different animal species, even among farms of distant geographical regions, implying that adaptive evolution of $S$. aureus has led to host dissemination. Close genetic relation as well as transmission of indistinguishable isolates among ovine and caprine isolates from distant herds are most likely associated with the low-input systems of goat and sheep production, which are the dominant systems practiced in Greece [11]. However, the underlying reasons for the spread of genetically related or indistinguishable $S$. aureus isolates among ovine, caprine, and bovine farms of distant geographical regions in northern Greece remain unclear, and further studies from broad geographical origins are needed to elucidate transmissibility between different host species, ensuring that this finding can be extended to the general S. aureus population.

Another focus of this study was the characterization of $S$. aureus isolates and the identification of specific genomic and phenotypic characteristics of the pathogen that could be associated with the outcome of mastitis in ruminants. To this end, we evaluated antimicrobial resistance; microbial cell surface traits such as the aggregation ability, hydrophobicity, and biofilm formation capacity; as well as virulence and resistance genes contributing to S. aureus pathogenicity.

Overall, by evaluating antimicrobial resistance, we found a low phenotypic antimicrobial resistance among all ruminant isolates. Since the cell surface hydrophobicity of $S$. aureus has been suggested to contribute as an adaptive reaction against antimicrobial 
agents [26], the low hydrophobicity we observed among all isolates is in accordance with the low antimicrobial resistance. A relatively higher resistance frequency was observed to penicillin $(16.7 \%, 27 / 162)$ and tetracycline $(14.2 \%, 23 / 162)$, consistent with previous studies in Greece [14] and in Europe [22,27] that noted penicillin or tetracycline as the primary resistance phenotypes. The low frequency of resistance to antimicrobials such as penicillin and tetracycline, which they usually used in veterinary medicine to cure mastitis, is strong evidence of the low pressure of antimicrobials in small ruminants in Greece [14]. A relatively higher resistance frequency to penicillin and tetracycline was observed among bovine isolates. This is indicative of a higher selective pressure due to the more frequent use of antimicrobials in bovines compared with low-input traditional goat and sheep herds, in Greece.

Regarding the virulence and resistance genes contributing to $S$. aureus pathogenicity, none of the isolates tested positive for the lukF-PV gene encoding the Panton-Valentine leukocidin (PVL) toxin and for the methicillin resistance genes, mecA or mecC; the latter confirms the evidence of the low isolation frequency of MRSA among isolates from goat, sheep, and bovine raw milk in Greece, as previously described [11,14-16]. We found a high number of different virulence gene profiles, revealing a diverse range of SE genes among isolates. The most frequent SE genes among the S. aureus isolates were sec and seb, while all isolates tested negative for see. Similar studies have also reported a high prevalence of the sec and seb genes among $S$. aureus isolated from small ruminants and bovines with mastitis $[8,15]$, while the absence of the enterotoxin gene see in our isolates is in accordance with previous results [10].

Numerous studies were accomplished in order to associate phenotypic and genotypic characteristics of $S$. aureus with the clinical or subclinical manifestation of mastitis in small ruminants and bovines [28-32]. In this aspect, we performed multiple correspondence analysis, revealing that the presence of the sec gene is associated with CM. These results corroborate those of previous studies that reported that sec is the most frequently isolated gene in animals suffering from mastitis $[33,34]$ and is recognized as an important virulence factor in bovine mastitis [31]. In addition, Fang et al. [33], using a mouse model, demonstrated that the enterotoxin SEC can directly cause inflammation, proinflammatory cytokine production, and tissue damage in mammary glands, suggesting that it might play an important role in the development of mastitis associated with $S$. aureus infection. Interestingly, correspondence analysis showed that the detection of the enterotoxin seg gene does not correlate with either CM or SCM, confirming the results of a previous study that stated that the seg gene is associated with a decreased likelihood of bacteria causing intramammary infections during lactation in dairy cows [35]. Regarding S. aureus cell surface properties, multiple correspondence analysis demonstrated that strong-biofilm-producing and high-autoaggregating $S$. aureus isolates were associated with CM, while moderatebiofilm-forming and low-autoaggregating isolates were related to SCM. Several studies have suggested that biofilm formation and autoaggregation are associated with epithelial adhesion and resistance to antimicrobial agents, enabling $S$. aureus to resist host immune defense mechanisms, and therefore are considered as important factors in the pathogenesis of intramammary infections [12,36,37].

In summary, this study revealed that sheep, goats, and bovines are exposed to a broad range of genetically diverse strains of mastitis-associated $S$. aureus that possess variable enterotoxin genes. We also provided evidence that $S$. aureus from ruminants is a clonal microorganism that spreads among different animal species and that pathogen isolates from sheep, goats, and bovines do not represent separate genetic populations. Furthermore, we showed that specific pathogen strains have the capacity to cause mastitis in different host species, even among farms of distant geographical regions. We also demonstrated that the outcome of mastitis in ruminants is associated with specific genotypic and phenotypic traits of $S$. aureus. However, the pathogenesis of $S$. aureus mastitis is complex, depending on host-pathogen interactions, which are determined by numerous factors such as host health, expression of virulence genes, and host immune system. Thus, it is likely that specific 
phenotypic traits such as biofilm capacity and aggregation ability as well as the presence of virulent genes alone cannot define the outcome of interactions with the host in vivo and the outcome of mastitis [28,30]. Therefore, further data are needed to understand the epidemiology as well as the bacterial factors that are associated with the severity of mastitis in ruminants. This work highlights the importance of understanding the population structure, transmission, virulence characteristics, and pathogenicity of $S$. aureus from ruminant mastitis in order to develop strategies for reducing the spread of the pathogen among herds in a specific geographical region.

\section{Materials and Methods}

\subsection{Bacterial Strains}

A total of 162 S. aureus isolates obtained from cases of ovine $(n=97)$, caprine $(n=29)$, and bovine $(n=36)$ CM or SCM were analyzed in this study. S. aureus isolates were selected from the strain collection of staphylococci maintained at our laboratory that comprised isolates collected at different time points over a period of approximately five years from farms located in northern Greece. S. aureus from SCM cases (25 caprine and 63 ovine) were obtained from bulk tank milk (BTM) samples from SCM-positive farms, whereas CM isolates ( 4 caprine, 34 ovine, and 36 bovine) were obtained after cultivation on agar plates of individual milk samples from animals suffering from CM. For BTM sampling, the criteria for selecting ovine and caprine farms positive for SCM were the presence of animals without any CM signs that produced milk with a somatic (body-derived; mainly leucocytes) cell count (SCC) of $>10^{6} / \mathrm{mL}$ measured by means of an automatic high-throughput analyzer (Fossomatic FC; Foss, Hilleroed, Denmark) - a value that indicates the manifestation of SCM [38]. For individual milk samples, the selection of animals with CM was based on the diagnosis of clinical signs of inflammation on the mammary gland (swelling, pain), macroscopic abnormalities in the milk (pus, lumps, and blood streaks), increased somatic cell counts, a positive California mastitis test, and decreased milk yield [38].

Isolation of staphylococci from milk samples was carried out on Baird-Parker agar supplemented with Egg-Yolk Tellurite (LAB M, Lancashire, UK) after incubation for $48 \mathrm{~h}$ at $37^{\circ} \mathrm{C}$, as previously described [11]. From plates displaying bacterial growth, up to four wellisolated black colonies, with or without an opaque halo (presumptive Staphylococcus spp.), were randomly selected and sub-cultured onto Tryptone Soya Yeast Extract agar (LAB M, Lancashire, UK) for $24 \mathrm{~h}$ at $37^{\circ} \mathrm{C}$ for purification and further characterization. Identification of $S$. aureus strains was based upon biochemical assays (Gram staining, catalase reaction, hemolysis, mannitol fermentation, tube coagulase test, and V-P reaction), followed by PCR tests for the detection of coa and the species-specific nuc genes. Overall, only one randomly chosen isolate per farm, containing sheep or goats or cows only, was considered for this study.

\subsection{DNA Extraction and Species Confirmation}

All phenotypically confirmed $S$. aureus strains were subjected to further molecular characterization. A DNA purification protocol for Gram-positive bacteria (Pure Link Genomic DNA kit; Invitrogen, Carlsbad, CA, USA) was used for genomic DNA extraction. The PCR conditions previously described by Zdragas et al. [14] were used for the detection of coa [39] and the species-specific nuc [40] genes in order to confirm the identification of all presumptive $S$. aureus isolates.

\subsection{Detection of Virulence and Resistance Genes}

Multiplex PCRs were used for the detection of virulence and resistance genes contributing to $S$. aureus pathogenicity. Two sets of primers (sea, seb, sec, seh, and sej; sed, see, $s e g$, sei, and tsst) were used to detect the genes of 10 types of SEs. PCR amplification and amplicon analysis by electrophoresis were performed, as described by Lovseth et al. [41]. The methicillin resistance genes $(m e c \mathrm{~A}, m e c \mathrm{C})$ and the lukF-PV gene encoding the Panton- 
Valentine leukocidin (PVL) toxin were detected by multiplex PCR using the primers and conditions described by Stegger et al. [42].

\subsection{PFGE}

PFGE analysis of $S$. aureus isolates was performed according to the PulseNet protocol [43] with the smaI enzyme (New England Biolabs, Beverly, MA, USA) by using a CHEF-DR III apparatus (Bio-Rad Laboratories Inc., Hercules, CA, USA) for the separation of DNA fragments. XbaI-digested DNA from Salmonella enterica serotype Braenderup $\mathrm{H} 9812$ was used as a reference size standard, while PFGE patterns were digitally analyzed using the FPQuest (Bio-Rad Laboratories Pty Ltd. Hercules, CA, USA) software package. PFGE profiles were compared using the Dice correlation coefficient, with a maximum position tolerance of $1.5 \%$ and optimization of $1.5 \%$. Similarity, clustering analysis was performed using the unweighted pair group method using averages (UPGMA), and a dendrogram was generated. Two PFGE profiles were classified as indistinguishable if the DNA fragment patterns matched each other completely, while clusters were selected using a cutoff at the $75 \%$ level of genetic similarity. The discriminatory power of PFGE analysis was determined using Simpson's index of discrimination (D), as previously described [44]. Values for D ranged between 0 and 1 , with a value of 1 indicating the most discriminatory method.

\subsection{Spa Typing}

spa typing was performed according to Aires-de-Sousa et al. [24]. The sequence data of the polymorphic regions of the spa gene were analyzed using the spa-typing plugin in BioNumerics v.8.0 software (Applied Maths, Sint-Martens-Latem, Belgium; under a temporary evaluation license; receiving permission to publish), which connects to the SeqNet/Ridom Spa Server (https: / / www.spaserver.ridom.de/ accessed on 25 February 2021). A minimum spanning tree (MST) was also generated in BioNumerics using the spa-clustering method of the spa-typing plugin.

\subsection{Biofilm Formation and Cell Surface Traits}

\subsubsection{Biofilm Formation}

The biofilm formation capacity of staphylococcal strains was determined using a semiquantitative, microtiter-plate (MTP) adherence assay according to the protocol described by Wang et al. [45], which measures the optical density (OD) of adherent biofilms stained with $0.3 \%(\mathrm{w} / \mathrm{v})$ crystal violet at $570 \mathrm{~nm}$. The cutoff optical density (ODc) was defined as the mean OD value of the negative control (plain broth medium). Depending on the resulting OD readings, S. aureus strains were classified according to Borges et al. (2012) [46] as no biofilm producers (OD $<$ ODc), weak biofilm producers (ODc $<$ OD $\leq 2 \times$ ODc), moderate biofilm producers $\left(2 \times\right.$ ODc $<$ OD $\leq 4 \times$ OD $\left._{C}\right)$, or strong biofilm producers $(4 \times$ ODc $<$ OD) .

\subsubsection{Autoaggregation Assay}

Autoaggregation assay was performed, as described previously [47], with slight modifications. Briefly, $4 \mathrm{~mL}$ of phosphate-buffered saline (PBS) containing $10^{8} \mathrm{CFU} / \mathrm{mL}$ of bacterial cells was resuspended by vortexing for $10 \mathrm{~s}$ and incubated for $5 \mathrm{~h}$ at room temperature. At $1 \mathrm{~h}$ intervals, $0.1 \mathrm{~mL}$ of the upper suspension was carefully removed and transferred to another tube containing $3.9 \mathrm{~mL}$ of PBS, and the A600 was measured. The experiment was repeated three times, and the autoaggregation percentage was expressed as a function of time until it was constant, using the following formula: Autoaggregation $(\%)=$ $1-(\mathrm{At} / \mathrm{A} 0) \times 100$, where At represents the absorbance at time $\mathrm{t}=1,2,3,4$, or $5 \mathrm{~h}$ and A0 is the absorbance at $t=0$. The degree of bacterial aggregation was classified as low $(0-69 \%)$ or high (70-100\%) [48]. 


\subsubsection{Cell Surface Hydrophobicity}

Bacterial cell surface hydrophobicity was determined by measuring microbial adhesion to hydrocarbons (MATH), as previously described [49], by using different organic solvents such as xylene and n-dodecane. Cells in the stationary phase were washed twice in PBS and finally re-suspended in $3 \mathrm{~mL}$ of $0.1 \mathrm{M} \mathrm{KNO}_{3}$ containing about $10^{8} \mathrm{CFU} / \mathrm{mL}$ of bacteria, and absorbance was measured at $600 \mathrm{~nm}$ (A0). One milliliter of xylene was then added to the cell suspension to form a two-phase system. After $10 \mathrm{~min}$ pre-incubation at room temperature, the two-phase system was mixed by vortexing for $2 \mathrm{~min}$. Then, the water and organic solvent phases were allowed to separate by incubation for $20 \mathrm{~min}$ at room temperature. The aqueous phase was carefully removed, and its absorbance (A1) was measured at $600 \mathrm{~nm}$, while $\mathrm{KNO}_{3}$ was used as a control. The experiment was repeated three times, and the percentage of cell surface hydrophobicity $(\mathrm{H} \%)$ was calculated using the following formula: $\mathrm{H}(\%)=(1-\mathrm{A} 1 / \mathrm{A} 0) \times 100$. The degree of bacterial hydrophobicity was classified as low (0-29\%), medium (30-59\%), or high (60-100\%) [50].

\subsection{Antimicrobial Susceptibility Testing}

S. aureus isolates were tested for their susceptibility by the standard disk diffusion method on Mueller-Hinton agar (Merck, Darmstadt, Germany) using commercially available discs (Oxoid, Basingstoke, UK) according to the Clinical and Laboratory Standard Institute (CLSI) guidelines [51]. The antimicrobial agents used were penicillin, cefoxitin, ceftazidime, amikacin, gentamicin, kanamycin, streptomycin, chloramphenicol, clindamycin, erythromycin, ciprofloxacin, tetracycline, trimethoprim/sulphamethoxazole, rifampicin, cephalothin, cefotaxime, ceftriaxone, vancomycin, ofloxacine, and tombramycin. Multidrug resistance was defined, as previously proposed [52]. S. aureus ATTC 25923 was used as the control strain.

\subsection{Statistical Analysis}

All experiments were carried out in triplicate. All statistical analyses were performed using XLSTAT software, version 2014.5.03 (Addinsoft, New York, NY, USA). Comparisons of proportions were evaluated using the chi-square test or Fisher's exact test, as appropriate. To understand the relationship between specific genotypic (enterotoxin genes) and phenotypic (biofilm formation strength, autoaggregation ability) characteristics of isolates and the severity of mastitis, multiple correspondence analysis (MCA) was performed. As the MCA method is not designed for hypothesis testing, interrelation of the analyzed variables was also examined by the chi-square test to further support the results of MCA. $p<0.05$ was considered statistically significant [53].

Supplementary Materials: The following are available online. Figure S1. Dendrogram of SmaI PFGE pulsotypes (P) and characteristics of the 162 S. aureus isolates, doi.org/10.5281/zenodo.4446115; Figure S2. Determination of biofilm formation capacity of staphylococcal strains, using a semiquantitative, microtiter-plate (MTP) adherence assay, doi.org/10.5281/zenodo.4518750.

Author Contributions: Conceptualization, C.K. and A.Z.; methodology, G.V., V.G., S.A., S.M., and A.M.; software, A.M. and C.K.; writing-original draft preparation, C.K.; writing-review and editing, S.D., A.Z., A.M. and E.L.; funding acquisition, A.Z. and E.L. All authors have read and agreed to the published version of the manuscript.

Funding: This research received no external funding.

Institutional Review Board Statement: The study was conducted according to the guidelines of the Declaration of Helsinki, in compliance with the Greek legislation, and the protocol was approved by the Ethical Committee of the Veterinary Research Institute, ELGO Demeter.

Informed Consent Statement: Not applicable.

Data Availability Statement: Not applicable.

Conflicts of Interest: The authors declare no conflict of interest. 


\section{References}

1. Hogeveen, H.; Huijps, K.; Lam, T.J.G.M. Economic aspects of mastitis: New developments. N. Z. Vet. J. 2011, 59, 16-23. [CrossRef]

2. Gougoulis, D.A.; Kyriazakis, I.; Fthenakis, G.C. Diagnostic significance of behaviour changes of sheep: A selected review. Small Rumin. Res. 2010, 92, 52-56. [CrossRef]

3. Wilson, D.J.; Gonzalez, R.N.; Das, H.H. Bovine Mastitis Pathogens in New York and Pennsylvania: Prevalence and Effects on Somatic Cell Count and Milk Production. J. Dairy Sci. 1997, 80, 2592-2598. [CrossRef]

4. Bergonier, D.; Sobral, D.; Feßler, A.T.; Jacquet, E.; Gilbert, F.B.; Schwarz, S.; Treilles, M.; Bouloc, P.; Pourcel, C.; Vergnaud, G. Staphylococcus aureus from 152 cases of bovine, ovine and caprine mastitis investigated by Multiple-locus variable number of tandem repeat analysis (MLVA). Vet. Res. 2014, 45, 1-8. [CrossRef]

5. Li, T.; Lu, H.; Wang, X.; Gao, Q.; Dai, Y.; Shang, J.; Li, M. Molecular characteristics of Staphylococcus aureus causing bovine mastitis between 2014 and 2015. Front. Cell. Infect. Microbiol. 2017, 7, 1-10. [CrossRef]

6. Le Loir, Y.; Baron, F.; Gautier, M. Staphylococcus aureus and food poisoning. Genet. Mol. Res. 2003, 2, 63-76.

7. Sergelidis, D.; Angelidis, A.S. Methicillin-resistant Staphylococcus aureus: A controversial food-borne pathogen. Lett. Appl. Microbiol. 2017, 64, 409-418. [CrossRef]

8. McMillan, K.; Moore, S.C.; McAuley, C.M.; Fegan, N.; Fox, E.M. Characterization of Staphylococcus aureus isolates from raw milk sources in Victoria, Australia. BMC Microbiol. 2016, 16, 1-12. [CrossRef]

9. Piccinini, R.; Tassi, R.; Daprà, V.; Pilla, R.; Fenner, J.; Carter, B.; Anjum, M.F. Study of Staphylococcus aureus collected at slaughter from dairy cows with chronic mastitis. J. Dairy Res. 2012, 79, 249-255. [CrossRef]

10. Wang, D.; Zhang, L.; Yong, C.; Shen, M.; Ali, T.; Shahid, M.; Han, K.; Zhou, X.; Han, B. Relationships among superantigen toxin gene profiles, genotypes, and pathogenic characteristics of Staphylococcus aureus isolates from bovine mastitis. J. Dairy Sci. 2017, 100, 4276-4286. [CrossRef]

11. Angelidis, A.S.; Komodromos, D.; Giannakou, R.; Arsenos, G.; Gelasakis, A.I.; Kyritsi, M.; Filioussis, G.; Hadjichristodoulou, C.; Torounidou, P.; Papa, A.; et al. Isolation and characterization of Staphylococcus aureus and methicillin-resistant Staphylococcus aureus (MRSA) from milk of dairy goats under low-input farm management in Greece. Vet. Microbiol. 2020, 247, 108749. [CrossRef] [PubMed]

12. Trunk, T.; Khalil, H.S.; Leo, J.C. Bacterial autoaggregation. AIMS Microbiol. 2018, 4, 140-164. [CrossRef] [PubMed]

13. Romanò, A.; Gazzola, A.; Bianchini, V.; Cortimiglia, C.; Maisano, A.M.; Cremonesi, P.; Graber, H.U.; Vezzoli, F.; Luini, M. Staphylococcus aureus From Goats Are Genetically Heterogeneous and Distinct to Bovine Ones. Front. Vet. Sci. 2020, 7, 1-9. [CrossRef]

14. Zdragas, A.; Papadopoulos, T.; Mitsopoulos, I.; Samouris, G.; Vafeas, G.; Boukouvala, E.; Aikateriniadou, L.; Kyriaki, M.; Alexopoulos, A.; Lagka, V. Prevalence, genetic diversity, and antimicrobial susceptibility profiles of Staphylococcus aureus isolated from bulk tank milk from Greek traditional ovine farms. Small Rumin. Res. 2015, 125, 120-126. [CrossRef]

15. Pexara, A.; Solomakos, N.; Sergelidis, D.; Angelidis, A.S.; Govaris, A. Occurrence and antibiotic resistance of enterotoxigenic Staphylococcus aureus in raw ovine and caprine milk in Greece. Dairy Sci. Technol. 2016, 96, 345-357. [CrossRef]

16. Papadopoulos, P.; Angelidis, A.S.; Papadopoulos, T.; Kotzamanidis, C.; Zdragas, A.; Papa, A.; Filioussis, G.; Sergelidis, D. Staphylococcus aureus and methicillin-resistant S. aureus (MRSA) in bulk tank milk, livestock and dairy-farm personnel in north-central and north-eastern Greece: Prevalence, characterization and genetic relatedness. Food Microbiol. 2019, 84. [CrossRef]

17. Merz, A.; Stephan, R.; Johler, S. Staphylococcus aureus isolates from goat and sheep milk seem to be closely related and differ from isolates detected from bovine milk. Front. Microbiol. 2016, 7, 1-7. [CrossRef] [PubMed]

18. Saei, H.D.; Ahmadi, M.; Mardani, K.; Batavani, R.A. Molecular typing of Staphylococcus aureus isolated from bovine mastitis based on polymorphism of the coagulase gene in the north west of Iran. Vet. Microbiol. 2009, 137, 202-206. [CrossRef]

19. Van Leeuwen, W.B.; Melles, D.C.; Alaidan, A.; Al-Ahdal, M.; Boelens, H.A.M.; Snijders, S.V.; Wertheim, H.; Van Duijkeren, E.; Peeters, J.K.; Van Der Spek, P.J.; et al. Host- and tissue-specific pathogenic traits of Staphylococcus aureus. J. Bacteriol. 2005, 187, 4584-4591. [CrossRef]

20. Mørk, T.; Tollersrud, T.; Kvitle, B.; Jørgensen, H.J.; Waage, S. Comparison of Staphylococcus aureus genotypes recovered from cases of bovine, ovine, and caprine mastitis. J. Clin. Microbiol. 2005, 43, 3979-3984. [CrossRef]

21. Aires-de-Sousa, M.; Parente, C.E.S.R.; Vieira-da-Motta, O.; Bonna, I.C.F.; Silva, D.A.; De Lencastre, H. Characterization of Staphylococcus aureus isolates from buffalo, bovine, ovine, and caprine milk samples collected in Rio de Janeiro State, Brazil $\nabla$. Appl. Environ. Microbiol. 2007, 73, 3845-3849. [CrossRef]

22. Concepción Porrero, M.; Hasman, H.; Vela, A.I.; Fernández-Garayzábal, J.F.; Domínguez, L.; Aarestrup, F.M. Clonal diversity of Staphylococcus aureus originating from the small ruminants goats and sheep. Vet. Microbiol. 2012, 156, 157-161. [CrossRef] [PubMed]

23. Papadopoulos, P.; Papadopoulos, T.; Angelidis, A.S.; Kotzamanidis, C.; Zdragas, A.; Papa, A.; Filioussis, G.; Sergelidis, D. Prevalence, antimicrobial susceptibility and characterization of Staphylococcus aureus and methicillin-resistant Staphylococcus aureus isolated from dairy industries in north-central and north-eastern Greece. Int. J. Food Microbiol. 2019, 291. [CrossRef] [PubMed]

24. Aires-De-Sousa, M.; Boye, K.; De Lencastre, H.; Deplano, A.; Enright, M.C.; Etienne, J.; Friedrich, A.; Harmsen, D.; Holmes, A.; Huijsdens, X.W.; et al. High interlaboratory reproducibility of DNA sequence-based typing of bacteria in a multicenter study. J. Clin. Microbiol. 2006, 44, 619-621. [CrossRef] [PubMed] 
25. Jørgensen, H.J.; Mørk, T.; Caugant, D.A.; Kearns, A.; Rørvik, L.M. Genetic variation among Staphylococcus aureus strains from Norwegian bulk milk. Appl. Environ. Microbiol. 2005, 71, 8352-8361. [CrossRef] [PubMed]

26. Lather, P.; Mohanty, A.K.; Jha, P.; Garsa, A.K. Contribution of Cell Surface Hydrophobicity in the Resistance of Staphylococcus aureus against Antimicrobial Agents. Biochem. Res. Int. 2016, 2016. [CrossRef]

27. Käppeli, N.; Morach, M.; Corti, S.; Eicher, C.; Stephan, R.; Johler, S. Staphylococcus aureus related to bovine mastitis in Switzerland: Clonal diversity, virulence gene profiles, and antimicrobial resistance of isolates collected throughout 2017. J. Dairy Sci. 2019, 102, 3274-3281. [CrossRef]

28. Hoekstra, J.; Zomer, A.L.; Rutten, V.P.M.G.; Benedictus, L.; Stegeman, A.; Spaninks, M.P.; Bennedsgaard, T.W.; Biggs, A.; De Vliegher, S.; Mateo, D.H.; et al. Genomic analysis of European bovine Staphylococcus aureus from clinical versus subclinical mastitis. Sci. Rep. 2020, 10,1-11. [CrossRef]

29. Rocha, L.S.; Silva, D.M.; Silva, M.P.; Vidigal, P.M.P.; Silva, J.C.F.; Guerra, S.T.; Ribeiro, M.G.; De Mendes, T.A.O.; De Ribon, A.O.B. Comparative genomics of Staphylococcus aureus associated with subclinical and clinical bovine mastitis. PLoS ONE 2019, 14, 1-19. [CrossRef] [PubMed]

30. Naushad, S.; Nobrega, D.B.; Naqvi, S.A.; Barkema, H.W.; De Buck, J. Genomic Analysis of Bovine Staphylococcus aureus Isolates from Milk To Elucidate Diversity and Determine the Distributions of Antimicrobial and Virulence Genes and Their Association with Mastitis. mSystems 2020, 5, 1-23. [CrossRef] [PubMed]

31. Haveri, M.; Roslöf, A.; Rantala, L.; Pyörälä, S. Virulence genes of bovine Staphylococcus aureus from persistent and nonpersistent intramammary infections with different clinical characteristics. J. Appl. Microbiol. 2007, 103, 993-1000. [CrossRef]

32. Pichette-Jolette, S.; Millette, G.; Demontier, E.; Bran-Barrera, D.; Cyrenne, M.; Ster, C.; Haine, D.; Keefe, G.; Malouin, F.; Roy, J.P. Partial prediction of the duration and the clinical status of Staphylococcus aureus bovine intramammary infections based on the phenotypic and genotypic analysis of isolates. Vet. Microbiol. 2019, 228, 188-195. [CrossRef]

33. Fang, R.; Cui, J.; Cui, T.; Guo, H.; Ono, H.K.; Park, C.H.; Okamura, M.; Nakane, A.; Hu, D.L. Staphylococcal enterotoxin C is an important virulence factor for mastitis. Toxins 2019, 11, 141. [CrossRef] [PubMed]

34. Etter, D.; Schelin, J.; Schuppler, M.; Johler, S. Staphylococcal Enterotoxin C-An Update on SEC Variants, Their Structure and Properties, and Their Role in Foodborne Intoxications. Toxins 2020, 12, 584. [CrossRef]

35. Veh, K.A.; Klein, R.C.; Ster, C.; Keefe, G.; Lacasse, P.; Scholl, D.; Roy, J.P.; Haine, D.; Dufour, S.; Talbot, B.G.; et al. Genotypic and phenotypic characterization of Staphylococcus aureus causing persistent and nonpersistent subclinical bovine intramammary infections during lactation or the dry period. J. Dairy Sci. 2015, 98, 155-168. [CrossRef]

36. Grunert, T.; Stessl, B.; Wolf, F.; Sordelli, D.O.; Buzzola, F.R.; Ehling-Schulz, M. Distinct phenotypic traits of Staphylococcus aureus are associated with persistent, contagious bovine intramammary infections. Sci. Rep. 2018, 8, 1-10. [CrossRef] [PubMed]

37. Fox, L.K.; Zadoks, R.N.; Gaskins, C.T. Biofilm production by Staphylococcus aureus associated with intramammary infection. Vet. Microbiol. 2005, 107, 295-299. [CrossRef]

38. Fragkou, I.A.; Boscos, C.M.; Fthenakis, G.C. Diagnosis of clinical or subclinical mastitis in ewes. Small Rumin. Res. 2014, 118, 86-92. [CrossRef]

39. Hookey, J.V.; Richardson, J.F.; Cookson, B.D. Molecular typing of Staphylococcus aureus based on PCR restriction fragment length polymorphism and DNA sequence analysis of the coagulase gene. J. Clin. Microbiol. 1998, 36, 1083-1089. [CrossRef] [PubMed]

40. Hygiene, F.; Sudagidan, M.; Aydin, A. Screening virulence properties of staphylococci. Wien. Tierarztl. Mon. 2008, 95, 128-134.

41. Løvseth, A.; Loncarevic, S.; Berdal, K.G. Modified multiplex PCR method for detection of pyrogenic exotoxin genes in staphylococcal isolates. J. Clin. Microbiol. 2004, 42, 3869-3872. [CrossRef] [PubMed]

42. Stegger, M.; Andersen, P.S.; Kearns, A.; Pichon, B.; Holmes, M.A.; Edwards, G.; Laurent, F.; Teale, C.; Skov, R.; Larsen, A.R. Rapid detection, differentiation and typing of methicillin-resistant Staphylococcus aureus harbouring either mecA or the new mecA homologue mecALGA251. Clin. Microbiol. Infect. 2012, 18, 395-400. [CrossRef]

43. McDougal, L.K.; Steward, C.D.; Killgore, G.E.; Chaitram, J.M.; McAllister, S.K.; Tenover, F.C. Pulsed-Field Gel Electrophoresis Typing of Oxacillin-Resistant Staphylococcus aureus Isolates from the United States: Establishing a National Database. J. Clin. Microbiol. 2003, 41, 5113-5120. [CrossRef] [PubMed]

44. Hunter, P.R.; Gaston, M.A. Numerical index of the discriminatory ability of typing systems: An application of Simpson's index of diversity. J. Clin. Microbiol. 1988, 26, 2465-2466. [CrossRef]

45. Wang, L.; Yu, F.; Yang, L.; Li, Q.; Zhang, X.; Zeng, Y. Prevalence of virulence genes and biofilm formation among Staphylococcus aureus clinical isolates associated with lower respiratory infection. African J. Microbiol. Res. 2010, 4, 2566-2569.

46. Borges, S.; Silva, J.; Teixeira, P. Survival and biofilm formation by Group B streptococci in simulated vaginal fluid at different $\mathrm{pHs}$. Antonie Van Leeuwenhoek 2012, 677-682. [CrossRef]

47. Kos, B.; Šušković, J.; Vuković, S.; Sǐmpraga, M.; Frece, J.; Matošić, S. Adhesion and aggregation ability of probiotic strain Lactobacillus acidophilus M92. J. Appl. Microbiol. 2003, 94, 981-987. [CrossRef] [PubMed]

48. Rahman, M.M.; Kim, W.S.; Kumura, H.; Shimazaki, K.I. Autoaggregation and surface hydrophobicity of bifidobacteria. World J. Microbiol. Biotechnol. 2008, 24, 1593-1598. [CrossRef]

49. Crow, V.L.; Gopal, P.K.; Wicken, A.J. Cell surface differences of lactococcal strains. Int. Dairy J. 1995, 5, 45-68. [CrossRef]

50. Niederle, M.V.; Bosch, J.; Ale, C.E.; Nader-Macías, M.E.; Aristimuño Ficoseco, C.; Toledo, L.F.; Valenzuela-Sánchez, A.; Soto-Azat, C.; Pasteris, S.E. Skin-associated lactic acid bacteria from North American bullfrogs as potential control agents of Batrachochytrium dendrobatidis. PLoS ONE 2019, 14. [CrossRef] 
51. Clinical Laboratory Standards Institute. Methods for Dilution Antimicrobial Susceptibility Tests for Bacteria That Grow Aerobically; Approved Standard-Ninth Edition. CLSI document M07-A9. Clin. Lab. Standars Inst. 2018, 32, 18.

52. Magiorakos, A.; Srinivasan, A.; Carey, R.B.; Carmeli, Y.; Falagas, M.E.; Giske, C.G.; Harbarth, S.; Hindler, J.F. Bacteria: An International Expert Proposal for Interim Standard Definitions for Acquired Resistance. Microbiology 2011, 18, $268-281$.

53. Kaklamanos, E.G.; Charalampidou, M.; Menexes, G.; Topitsoglou, V.; Kalfas, S. Transient oral microflora in Greeks attending day centres for the elderly and residents in homes for the elderly. Gerodontology 2005, 22, 158-167. [CrossRef] [PubMed] 